\title{
Sanat Terapisinin Felsefi Boyutları
}

\author{
Philosophical Aspects of Art Therapy
}

\begin{abstract}
Şahin FíLiz*
Öz: Sanat terapisi modern zamanların icadı değil; kökleri antikçağa kadar uzanan evrensel bir terapi yöntemidir. Mağara duvarlarına resim çizmek, ölüleri mumyalamak, tören maskeleri oymacılı̆̆ yapmak, parşömenler üzerine resim çizmek, modern zamanlarda grafik çizmek, resim yapmak, hamur ve çamur maddeleri kullanarak bir takım biçimler yaratmak hep sanatla terapinin tarih boyunca süregeldiğini gösteren örneklerdendir. Sanatla terapi, ruhun realitesini biçim ve çizgilerle yansıtarak hastayı tedaviye odaklanmış iken, onun düşünsel temelini oluşturan sanat, doğrudan doğruya sürrealizm, ekspresyonizm, fenomenoloji ve varoluşçulukla ilgilidir. Tik ile bağlantısı da ayrıca vurgulanmalıdır. Bu felsefi boyutlar bilinmeden, konusu salt insan olan sanatla terapinin anlaşılması ve uygulanması resmin, çizgilerin ve biçimlerin, düşünsel ve büyüsel derinliğini kavramaya yetmeyecektir. Çünkü sanat, sıradan olanı, sıra dışı deneyime çevirmenin yoludur. Bir bilme ve ruhsal olanı yansıtma yöntemi olarak sanat, eğer terapi ile iyileştirmek gücüne sahipse, o zaman gerçekten insan için bilmenin ve kendini gerçekleştirmenin en iyi yolu sayılabilir. Sanat, insanın sonsuz çelişkileri ile bireysel içgüdüsel dürtüleri ve toplumun talepleri arasında uzlaşma sağlamasına yardımcı olur. Fenomenoloji, XX. yüzyıl psikolojisine çok derin tesiri olan çağdaş bir felsefe akımı olarak, varoluşçuluk, aksiyoloji ve epistemoloji kuramları ile psikoloji-sanat ve sanat-sanat terapisi arasındaki doğal ilişkiyi vurgulayan eleştirel bir felsefi yöntemdir. Dolayısıyla sanatla terapi, çok bileşenli felsefi boyutları olan bir yöntemdir.
\end{abstract}

Anahtar sözcükler: Sanat, Felsefe, Terapi, Katharsis, Psikoloji, Ölüm

Abstract: Art therapy is not an invention of modern times; but is a universal therapy method whose roots date back to ancient times. From drawing pictures on cave walls, embalming the deaths, making carvings of ceremonial masks to drawing pictures on parchment, painting, drawing graphics, creating forms with dough and mud in modern times have always been examples of art therapy throughout the history. The intellectual basis of art is directly related to Surrealism, Expressionism, Phenomenology and Existentialism, while art therapy focuses on the treatment of patients by reflecting the reality of the spirit with the forms and the lines. Connection of art therapy with ethics should also be emphasized. Without knowing those philosophical dimensions, it will not be possible to comprehend and implement the spiritual and magical deepness of pictures, lines and forms. Because art is a way of converting the ordinary one into the extraordinary. If art has the power to improve therapy, as a means of knowing and reflecting the spiritual one, then it can be counted as the best way to self-realization and comprehension for human. Art helps people to reconcile between endless contradictions with instinctive drives of the individual and the demands of the society. Phenomenology, as a modern philosophical movement which deeply influences 20th century psychology, is a critical philosophical method emphasizing the natural relationship between existentialism, axiology and epistemology, psychology, art theory and art and art therapy. Therefore, art therapy is a method of multicomponent philosophical dimensions.

Keywords: Art, Philosophy, Therapy, Catharsis, Psychology, Death

\footnotetext{
*Prof. Dr., Akdeniz Üniversitesi, Edebiyat Fakültesi, Felsefe Bölümü, Antalya. sfiliz@akdeniz.edu.tr
} 


\section{A. Ahlak, Sanat, Felsefe}

"Sanat, insanın kaderine karşı en tutkulu isyanıdır"

Andre Malraux (1994).

Felsefenin en temel sorunsalları içinde ahlak ve sanat, salt insanı tanımlayan değerlerdir. Ontoloji ve epistemoloji de insanın varlık ve bilgi sorunlarını inceler; insan öznesi bakımından varlığı ve bilgiyi ya doğrudan onunla ya da dolaylı olarak ona ilişkin olarak sorun edinir. Ancak ahlak ve sanat, doğrudan doğruya insanı ve onun yapıp-etmelerini konu alır; kavramlaştırır ve yeniden insana döner. Ana tema, doğrudan ahlak-sanat işbirliği olmamakla birlikte, ahlak ve sanatın ikisi de canlı türleri arasında yalnızca insana özgü olması bakımından, zaman zaman birlikte alınmıştır.

\section{Aristoteles, sanatı ahlaki bir katharsis olarak görür. Sanatlartn ereği ona göre moral bir arınmadır. Sanat, estetik bir hoşlanma için değil, ama ahlaki bir değer için belirlenir; bu ahlaki değer, katharsis sürecinde nes- nelleşir. Sanatın görevi insanda estetik haz uyandırmak değil, etik bir haz yaratmaktır. Bu etik haz, ruhumuzun arınmast, boşalmastyla meydana gelir (Tunal1 1983, 114).}

Aristoteles, ahlak ile sanatı birbirinden ayırmamıştır. Kategorik olarak ayrılmaları sonraki dönemlere rastlasa da, ahlak ve sanat, insanı diğer varlık türlerinden ayıracak kadar insana özgü değerler olduğu için, hiç olmazsa sanat terapisi açısından onları ayrı ayrı düşünmenin açıklayıcı bir gerekçesi yoktur.

Süje, estetik obje, estetik değer veya güzel, estetik yargl olmak üzere estetik fenomen veya estetik yargı, bu dört faktörün ortak bütünlügü olarak meydana gelir. İşte felsefi estetiğin konusunu bu ortak bütünlük teşkil eder. Buradan felsefi estetik ile psikolojik estetik ve sanat felsefesi, güzel felsefesi veya estetik değer mantı̆̆ arasındaki ilişkiyi yakından görmek mümkün olmaktadır (Tunalı 1983, 114; Demiralp 2015, 19).

Felsefi estetik, holistik bir güzel felsefesidir. Sanatın, estetik fenomenin, holistik olması zorunlu ve kaçınılmazdır, çünkü insanı tüm varlık ve varoluşuyla çepeçevre sarabilmesi, felsefenin temel problemlerinden biri olması sayesindedir. İnsanın bütüncül güzel arayışını sanat nasıl ve ne yolla belirler? Güzel ile varlık, güzellik ile varoluş arasında nasıl bir bağ vardır?

Güzelliğin tözsel olarak belirlenmesi, Platon'un özellikle Şölen (Symposion) diyalogunun ana konusunu oluşturur. Şölen'de güzelliği kavramanın yolu Eros'tur. Eros, güzel olana kavuşmak, ondan doğurmaya, yaratmaya varabilmektir. Güzel-olanda yaratmaya ulaşabilmek isteği, aynı zamanda ölümsüzlüğe karşı duyulan derin varoluşsal istekle aynı şeydir. Tanrıların ölümsüz olmalarına karşılık, insanda ölümsüzlüğe karşı duyulan bir içtepi vardır. İnsanı ölümsüzlüğe götürense, Eros’tur. Eros, beden güzelliği ve ölümsüzlüğünden ruh güzelliği ve ölümsüzlügüne yükselir. Sonunda Eros bizzat güzelliğin kendisine yönelir. Mutlak güzel veya öz güzelliği, bütün güzelliklerin tepe noktasında bulunur. $\mathrm{O}$, yalnız güzel değil, aynı zamanda hakiki varlıktır. Çünkü varlığın ereği iyi ve güzel olmaktır (Tunalı 1983, 32).

Platon ontolojiden etiğe sanatın bütüncül bağlamını bu şekilde kurarken yalnız değildir. Öğrencisi Aristoteles ve yine mistik filozof olan diğer takipçisi Plotinus, sanatın başlıca felsefi bir değer olduğunu vurgulamaktadırlar. Güzeli ya da estetik objeyi, değil kendi içindeki ontolojik öğelerden arındırarak anlamak, felsefenin diğer temel sorunlarından ayrı olarak ele almak mümkün değildir. Sanat, felsefi bir bütünlük içinde hayat ve insanla buluşabilen bir sorunsaldır. 
Din, Tanrı, mitoloji dâhil, insan ve insana ait her şey, estetik objenin, dolayısıyla sanat fenomeninin gerçekleşme sürecindeki doğal yerini alır. Sanatçı insan ise, sanatsal güzelin muhatabı da insandır. Süje ve objenin bu denli birbiriyle kaynaştığı başka bir süje-obje ilişkisi bulmak kolay değildir. Başka bir deyişle, sanat ile sanat eseri, sanat fenomeninden ayrılmaz.

Sanat, felsefi bir değer olarak, doğru-yanlış, iyi-kötü, var-yok gibi bazı kategorik ayrımlara da kapalıdır. Sanat fenomeni, salt estetik hazzın ötesine geçerek hemen her türlü zıtlıkları eşitler; estetik yargıyı bütün diğer yargıların üstünde görür. Çünkü sanat, süjesi ve aynı zamanda nesnesi olabilen insanın aynası olarak, karmaşık doğaya sahiptir. İnsan kadar karmaşık doğası olan belki de onun yarattığı, kendi varoluşuna ayna tutan sanatıdır. Bunun yanında, insan yaratısı olan estetik objeye ve değere tanrısal nitelik yüklemek antik Yunan'dan beri varlığını korur. Hatta güzel ve güzellik, felsefi arayışın sonunda öyle bir noktaya gelir ki, orada ne insani ne de doğal bir güzellikten söz edilmez olur.

Platon'a göre bütün güzellikler tanrısal güzellikten pay alır. Plotinus da güzelliğin Nous yoluyla nihai kaynă̆ olarak Mutlak Bir'i işaret eder. Platon, gerçek erdemi yaratan ve besleyen özne olarak insanı gösterir. Insan bu sayede ölümsüzlüğe Mutlak Güzellikle ulaşır. Kendi başına bu güzelliğe erişme yetkinliğinde olan insan mutluluğu elde eder. Salt güzelliği Eros ile kavrayan kişi, aynı zamanda kendi başına iyiyi de ve bundan ötürü hakikati de kavrayacaktır; çünkü iyi ve güzel aynıdır (Tunalı 1983, 35).

Platon, iyi ve güzelin kaynağını tanrısal olarak değerlendirmektedir. Mutlak güzellikten pay alan insan, nihai mutluluğu da erişebilir. Hakikat ve güzellik, aynı kaynaktan geldiğine göre, mutluluğu elde eden insan, ahlaki erdemle sanatsal güzeli birleştirmiş olacaktır.

Terapi, böyle bir sanat görüşüyle gerçekleşmektedir. İnsan tüm gücüyle sanat fenomenini ortaya koyar. Karmaşık bir varlık olarak, sanatını, reel hayatının bir temsili olarak yaratır. Orada kendi karmaşıklığını, yine kendisi ama dışarıdan da temaşa edebilen bir özne olarak anlamlandırır. Transferini, varlıkta, bilgide, etikte ve nihayet sanatta en yüce olanda odaklar.

Plotinus, Platon ve Aristoteles'in yolundan giderek katharsisin güzel ile gerçekleşeceğini belirtir. Varoluşsal ve kalıcı bir mutluluğa götüren yol, Salt güzel ve güzelliğe ulaştıran yoldur. Diğer mutluluk yolları göreli mutluluk sağlar. Schopenhauer $(2015,339)$ göreli mutluluğun üç kaynaktan ileri geldiğini savunur: İlki, kişinin olduğu şey, ikincisi, kişinin sahip olduğu şey, üçüncüsü de kişinin diğerlerinin gözlerinde temsil ettiği şeyler”.

Oysa salt güzelliğin kaynağı, hiçbir tanıma sığmayan hakikat ve bu hakikatte gömülü iyi ve güzeldir. Sanat, katharsis'i ve sonucunda gerçekleşecek olan mutluluğu, göreli yollarda değil, iyi ve güzelin kaynağı olan salt hakikatte arar. Plotinus güzel yoluyla katharsis'in mümkün olduğunu söyler.

Plotinus'a göre ruhun güzelliği algyyla kavranabilir olan bir güzellik olmayıp o, ruh tarafindan doğrudan doğruya kavranır. Çünkü ruhun güzelliği, ruha göre aşkın olan bir güzellik değil, içkin bir güzelliktir. Katharsis'e dayanır. Bu da ancak ahlaki bir güzellik olabilir. Çünkü ahlaki güzellik genel olarak iyi eylem ve erdemle aynı şey olmuş olur. İyi, hyle'den kurtulmuş olandır. Hyle'ye bulanmış olan kötü ve çirkindir. Güzel aynı zamanda iyi olduğu için, Nous, doğrudan doğruya güzel olan şeydir; Nous ruhu güzelleştirir; sonra şekil veren ruhtan, davranışlardaki ve eylemlerdeki güzellik meydana gelir ve son olarak da güzel 
olarak adlandırllan bedenleri bu ruh güzel kllar. Zira ruh, tanırsal bir şeydir ve güzelin belli ölçüde bir parçasıdır; bundan ötürü de onun dokunduğu ve hâkim olduğu şey güzelleşir. Ahlaki karakterde olan bu güzel, kaynă̆ını Bir'in ilk taşması olan Nous'ta bulur. Güzel ve aynı zamanda iyi, maddeden, karanlıktan olabildiğince katharsis'tir. Arınma ne denli fazla ise güzellik o derece güçlüdür (Tunalı 1983, 50-51).

Peki, bu sanatsal yolculuk, gerçek varlığa erişebilir mi? Erişmedikçe iyi ve güzeli bir arada nasıl görüp mutlu olabilecektir?

"Platon, sanatl, sanat eserini marangoz-masa örneğinden hareketle bir gerçeğin 'kopyasının kopyası' olarak değerlendirir. Bu kavrayışı ve bakışında sanatı duyguların denetimsiz coşkusunun eseri olarak görüp eleştirse de sanat terapisi açısından çok önemli bir noktanın altını çizer. Ona göre, sanat eseri bir gerçeğin özgün varliğg değil, bir kopyanin kopyası olacaktır. Ne ki mimesis etkinliği ile gerçek varliğa hiçbir zaman erişilemez" (Tunalı 1983, 80-81).

Modern bilim yöntemi ve düşünme biçimin etkisiyle, Otto Rank'ın (1989, 3-69) dediği gibi insanın karmaşık doğasını atladığımız bir gerçektir. Tek yönlü, mekanik, olgucu düşünmenin sınırları içindeki insan için, antikçağ Yunan sanat görüşündeki bu metafiziksel çıkışlar, sanat terapisi için modern zamanlardaki teknik insan tanımı için bir çıkış noktası niteliğindedir. $O$ da sanatın hakikat yolunda insanın bütüncül ve aşkın mimetik mücadelesidir. Varoluşsal estetik, sanatsal biliş ve insanın karmaşık doğasının tüm güçlerini seferber edebileceği kültürel, simgesel bir benlik inşası bu yolculuğun yönünü iyi ile güzel transandantal bir hakikatte birleştiği varlığa yöneltecektir. Çünkü sanatla terapi, ucu açık bir süreçtir. Felsefe, hakikat arayışındaki varoluşsal, epistemik ve etik yolcuğuna olan hazırlığını, sanatla tamamlamış olacaktır. Terapi bu yolculuğun yönteminin ifadesidir.

Her ne kadar felsefeyle terapi ve sanatla terapi ayrı anılsalar da, ikincisi birincisinin bir parçasıdır. Sanatla terapi, içinden çıktığı felsefeden kaynaklansa da, çok eski bir terapi yöntemi olsa da, felsefe kliniklerinin kurumsal olmak için zamana ihtiyacı vardır. Gerçi ilk felsefe kliniklerinin kuruluşu en erken 1982'ye kadar gider.

“Ilk felsefi klinik Almanya'da bu tarihte Gerd Achenbach tarafindan kurulmuştur. Almanya'da klinik sayısı yüzleri bulmuştur. Fransa'da felsefi kafeler yakın tarihlerde ortaya çıktı. ABD'de 1990'ın başında ilk felsefi klinikler kuruldu. Hepsinin ortak yanı, Sokratik yöntemi içeren toplumsallık ve diyalogdur. Amaç, birliğe varmaktır. Bütün felsefe tarihinin büyük metafizik spekülasyolarında ortak amaç, iş̧e bu birliğe, varoluşsal birliğe ulaşmaktır. Örneğin bu birlik ideası Platon'da iyikötü; Meister Eckhardt'da ruh kurulumları; Spinoza'da töz; Leibniz'de Monad'dir" (Mussenbrock 2013, 87).

\section{1. Çoklukta Birlik}

Görünüş ve oluş aleminin bir yanılsama olduğu düşüncesine itiraz eden varlıkta birlik anlayışı, İslam mutasavvıflarının tasavvuf felsefelerinde ihmal edilmemiştir. Sanat, felsefenin birlik ideasının içerdiği "düzen, form ve simetri”yi, estetik objeye taşıyarak bu birliği "güzel” kavramıyla dile getirmiş; birliğin hakikatine, varlığın gerçekliğine estetik tavırla ulaşmaya çalışmıştır. Sanat, felsefenin hazırladığı ontolojik ve epistemolojik temel üzerinden estetik birliği 
hedeflemiştir. Bu anlamda felsefesiz sanat düşünmek, sanatsız bir insan düşünmek kadar akı1 dışıdır. Her ikisi insandan ve insan için olduğuna göre, psikolojinin terapiyi bunlar olmadan yapması da aynı mantıksal çelişkiyi doğurur. Öyleyse sanat terapisi, felsefesiz olmaz; psikoterapi de sanatsız olursa terapi salt "hasta-analist" düzleminde sıkışır.

Kendini tanıma süreci, klinik bir problem olmaktan daha fazla bir şeydir ve sonucu belirlenemez. Sanat terapisti işte bu yüzden psikoterapist değildir. Çünkü psikoterapötik "kurgu"burada "sağllklı" terapist, karşıda "rahatsız" hasta-bir hakimiyet ve bağımlılık yapısı ortaya koyar; felsefi terapi ya da sanatsal terapi ise tam da bu kurguya karşı durur. Kendini tanıma arayışı bir hastalık değildir ve bu yüzden onu tedavi edecek ya da kökünü kazıyacak bir doktora ya da terapiste ihtiyaç duymaz. $\mathrm{O}$, insan olmanın iyi düşünülmüş bir yoludur. O halde sanatla terapi kavramı nasıl yan yana gelir? Anlamı nedir?

\section{Sanat Terapisi}

..."Sanat sanat içindir" formülünden çıkarılan nahoş sonuçlar, genelde, sanatın başlı başına bir amaç olduğu inancına değil, insan hayatının yegâne veya en yüce amacı olduğu inancına dayanır”.

A. C. Bradley (1991).

Sanatla terapi, genel olarak felsefi terapi ya da felsefi danışmanlığın özel bir adı olarak tercih edilebilir. Felsefi terapinin özel bir alanı olarak sanatla terapi kendini tanıma, kendini tanımak için düşünme, zaman ve cesaret gibi temaları işler.

Kendi içine yönelmek her zaman kendini belli biçimde sınırlandırmak demektir. Krizler, kendi varlığımızın sorumluluğunu maddi ve manevi olarak dış güvencelere bırakmaya iter. Varoluşla bilinçli bir mücadeleye girmek, ara vermek ve varoluşun alanını tanımak ve orada yaşamak demektir. Bu şekilde yaşanılan varoluş, kendi sınırlarını bilir ve her türlü sınır kaldırıcı bozma girişimine karşı, belirgin karşı-çizgi çeker (Mussenbrock 2013, 63). Çok yönlü ve yöntemli olup hem anlamaya hem de sağaltıma dayanır. Hem çok genç hem de oldukça eski olması bir paradokstur. Tedavi için sanat, mağara duvarlarına resimler çizmekle başlatılabilir. Ancak bir meslek olarak hala ruh sağlı̆̆ ile ilgilenenler için çok yeni bir bilimdir. İlk insandan sanatçılara kadar uzanan çizgide ilkel sağaltımdan bilimsel sağaltıma kadar uzun bir geçmişi vardır. Bu nedenle sanat terapisi olabildiğince çok yönlüdür ve pek fazla farklı yüzü vardır. Judith A. Rubin, sanatı bir terapi olarak öne sürmek için klinik tedavi uzmanı olarak eğitilmiş olmayı esas kabul eder. Ona göre sanat ve terapi hakkındaki bilgileri bir araya getirebilmek için sadece kurs değil aynı zamanda, hastalara saatlerce danışmanlık yapılması ile elde edilen yoğun klinik eğitimi içeren iki yıllık önlisans çalışmasını gerekli görmektedir. Sanatla terapiyi ve bu alanda uzmanlaşmayı, salt modern bir uğraş alanı olarak kavrarsak, Rubin'e katılmakta bir sakınca bulunmaz. Hatta sanat terapistini ehil bir sanatkâr olma niteliği ile psikoterapi ve eğitim alanındaki özel becerileri birleştiren uzman diye tanımlayan Edith Kramer'i de aynı şekilde onaylamak olasidır (Rubin 2010, 69). Ancak Platon, Aristoteles ve Plotinus'ta tarihsel ve düşünsel köklerini bulan sanatın, modern zamanlarda salt süreli ve belirli bir eğitim ve deneyim ile bütüncül bir terapiye eriştirmesi tartışmalıdır. Kaldı ki, ürettiği ve kullandığ 1 teknoloji, varoluşunu sıkıştırdığ 1 tek yönlü tanım, mantıkçı-olgucu yönteme tanıdığ 1 imtiyaz yaşadığ modern zamanların dayattığı indirgenmiş bir hayata mahkum etse de insan, sanatı iyi ve güzel birlikteliğini arayabileceği hakikate doğru yolculuk olarak tanımlanmasından önceki zamanlardan beri karmaşık doğaya sahip olmayı sürdürmektedir. Rubin de zaten sanat terapisinin kaynakları, çok eski ve evrensel bir tedavi yolu olması, dayandığı tarihsel köklerin sağlamlığı ve 
derinliğinden söz ederken üstü kapalı olarak bu görüş doğrultusunda değerlendirmeler yapmayı ihmal etmemektedir. Sanat sıradan tecrübeyi sıra dışı yapmanın bir yoludur. Bilmek, ruhi olarak kavramak ve estetik bir deneyim demektir. Eğer terapi tedavi etmek ve daha doğrusu, iyileştirmek anlamına geliyorsa, o halde sanat gerçekten insan için ideal ilaç olabilir. Benliği bilmek ve harekete geçirmek için ruha en iyi yol olabilir.

Sanatın niçin tedavi edici olduğu hakkında düşünmenin pek çok sebebi vardır. Psikolog Ley bu nedenlerden birini isabetle şöyle tanımlamaktadır: "Bir kimse sol beyin yarım küresini săg beyin yarım küresinin kilidini açmak için kullanamaz". Jakab ifade etmektedir ki, "Sanat psikoterapisinin sözsüz yönü, zihinsel sağllk çalışması alanındaki önemli ve eşsiz durumu kurar. Çünkü bu hastalara (müşterilere) kendi gözleriyle dinleme firsatı verir" (Akt. Rubin 2010, 92). Edith Kramer ise, sanatın, bireyin içgüdüsel dürtülerle toplumun ondan talepleri arasındaki sonsuz çatışmayı uzlaştırması için insana yardım ettiğini, bu nedenle sanatı tüm çeşitleriyle, kelimenin en geniş manasıyla terapötik olarak nitelendirir (Akt. Rubin 2010, 92). Sanat tüm çeşitliliği ile insanın varoluşsal bütünselliğine hitap eder. Georg Simmel'in deyimiyle, sanatın bizi varoluşun bütün ayrıntılarından ve tek yanlılığından kurtarması, belki de sanattan kaynaklanan bireyselliğe özgü sınırsızlığın, içimizde hayat bulmasındandır (Akt. Artun 2015, 48).

Jean Baudrillard'ın sanatın gittikçe hayat olmak eğiliminde (Artun 2015, 18) bulunduğunu belirtmesi, felsefi gücü ve kapsamı açısından modern psikiyatriden daha fazlasını ifade ettiğini söylemenin başka bir yorumu olsa gerektir. Modern insan, modern psikiyatrinin kendisine sunduklarından daha fazlasına muhtaç görünmektedir.

Ernst Becker, modern insanın hayatının anlamını psikolojik içebakışta aramaya mahkûm edildiğini ileri sürer. Dolayısıyla insanın yeni günah çıkaran papazı, içebakıştaki en üst otorite, psikanalist olmak zorundadır. Freud'un tıp kökenli olmayan öğrencisi Otto Rank, böyle bir psikanalizin hastanın duygusal hayatını yavanlaştırdığını söyler. İnsanoğlu sevgisini mutlak bir güce ve değere odaklamayı ister ve analist ona her şeyin ilk şartlanmasına indirgenebileceğini söyler "İnsanoğlu mükemmeli keşfetmek ve tecrübe etmek ister ve analist ona her şeyin ne kadar gerçeğe bağlı olduğunu, en derin ontolojik güdülerimizin ve suçluluklarımızın klinik olarak açıklanabilir olduğunu söyler. Böylece insanoğlu ihtiyaç duyduğu mutlak gizemden yoksun kalır ve geriye kalan tek kadir-i mutlak şey bunu açıklayan insandır. Dolayısıyla hasta analiste bütün gücüyle bağlanır ve analizin bitmesinden korkar" (Becker 2013, 267).

Otto Rank’a (1989, 37) göre, Ortaçağlarda Tanrı'nın oturduğu tahta modern çağda psikiyatr oturmuştur. Tanrı'ya yüklenen insanüstü nitelikler ve beklentiler aynıyla psikiyatra atfedilmiştir. Psikoterapi, din felsefesi ile değil belki ama metafizik ve din ile başka bir formda kesişerek bu çıkmazı aşabilir. Çünkü sanat terapisi modern bir icat değildir. Estetiğin, güzelliğin, sakinleştirici, dinlendirici ve hatta çirkin duyguları bile ihtiva edici gücü tam da insanın karmaşık doğasının tüm dokularına nüfuz edebilecek derinliğe sahiptir. Doğal ya da sanatsal güzellikten çıkardığımız hazlar, sahip olduğumuz sözsüz formların bu denli değerli olduğunu, çünkü onların doğumdan ölüme kadar tümüyle içimizde taşıdı̆̆ımız söze gelmeyen tarifsiz duygularımızın bir aynas1, yansıması ve ifadesi olduğu görülmektedir.

Biz sanat icra etmek için nesnelere dokunduğumuz ya da onları biçimlendirdiğimizde, dünyaya temas etmenin tecrübesini yaşıyoruz demektir. Gerçekten de böylelikle hali hazırdaki varlığımızı hissetmekteyiz. Yaratma doğal olarak vardır. İnsan yaratırken-çizer ya da boyarken yeme-içmeyi, seksi bile iptal edebilir.

İmajın, yani görüntü ya da resmin büyülü bir gücü vardır. Sanatçılar, kendi yaratıcı güçleri kadar kendi imgelerinin kaynağını bulmak için sürekli içe dalarlar. $\mathrm{Bu}$, son zamanda değil, 
insanın içindeki dünyayı keşfetme, bilme ve temsil etme saygın bir estetik hedef olarak belirlenmiş olmasının çok eskilere kadar giden geleneği vardır. Felsefenin temel meseleleri sanat icraatında yöntem belirleyici, içerik tayin edici ve imgelere anlam verici olmak üzere yapıtın başından sonuna dek etkindir. Felsefesiz bir sanat ve sanatsız bir terapi işte bu yüzden düşünülebilir olmaktan çıkmaktadır.

İçe dalma yöntemi ile sanatçılar ruhlarında gömülü realiteleri yansıtırlar. Bu ekspresyonizm ve sürrealizm gibi akımların temelidir: Duyguları renk ve çizgilerle betimlemek, Edward Munch'ın The Scream'indeki gibi ya da rüyanın irrasyonel manzarasını göstermek şeklinde veya Salvador Dali'nin resimlerinde olduğu gibi örnekler verilebilir.

Akut zihinsel sıkıntılara maruz kalmış insanların kendilerini daha doğrudan resim, çamur ve pastel diliyle ifade etmeleri sanat terapisi açısından daha doğrudur. Sanat terapisti, ehil bir sanatkâr olmanın yetkinliği ile psikoterapi ve eğitim alanındaki özel becerileri birleştirebilen bir uzmandır.

\section{Niçin Sanat ve Sanat Terapisi?}

Sanat, sıradan olanı, sıra dışı deneyime çevirmenin bir yoludur. Sanat, bir varoluş tarzı, bir bilme ve eyleme şeklidir. Bir başka açıdan ise, ruhsal bir yol, ruhani bir yolculuktur. Benliği anlamlandırmanın ve gerçekleştirmenin en iyi yolu sayılabilir. Benlik anlamlandırılıp gerçekleştirildiğinde sanat, insanın kendi içindeki sonsuz çelişkisi ile bireysel içgüdüsel dürtüleri ve toplumun talepleri arasında uzlaşma sağlamasına yardımcı olabilir.

Sanat eserlerinin her biri, terapide ayrı öneme sahiptir.

Freud'a göre edebi bir sanat olan şiir, doğurduğu imgesel tasarımlarla bizi iç baskılardan kurtarır, dışarı saldıran güçlere yol verip onları tehlikesiz bölgelere akıtır.

"Gerçek sanat yapıtında biçim ve figür yaratmak bir kendinden-öteye yaratmaktır. Goethe kendi yerine Werther'i öldürmek suretiyle kendini kurtardı̆̆ını söylediğinde psikolojinin çok esaslı bir gerçeğini dile getirmiş oluyordu: kafasinda tasarladiğ intihar fantezi aynasina yansittığ uydurma bir figüre aktararak boşaltmış ve kendini böylece o düşüncenin baskısından kurtarmıştır... Kişisel düşler nasıl tek tek insanların sevinç ve kederlerini dile getiriyorsa, dinlerle mitlerin plastik şekillerinde ve canlı figürlerinde de halkların korkuları ve istekleri yankılanmaktadır" (Zweig 1996, 90).

Gerçek sanat yapıtı biçim ve figürlerde insanın kendinden öteye geçmesi; esasen kendi varoluşsal sınırlarını keşfetmesi anlamına gelir. Dinler, bu sınırları, insanın metafizik varlık evreninde aramasının tinsel bir göstergesidir ve bu bakımdan dinlerdeki biçim ve figürler de sanat terapisinin hem nesnesi hem de öznesi olabilir.

Dinlerde muhtemel antipatik yönler bu sanatsal biçimlerle hafifleme hatta sağaltıcı etki yaratma istidadına sahiptir. Edgar Morin, sinemanın, günlük yaşamımızın dayanılmaz sıradanlığı ve bilinçsizliğine karşı bir uyarıcı etki yaparak, sıradanı sıra dışı haline getirme sanatı olduğunu söyler ve terapik özelliğine dikkat çeker:

İnsanın iç dünyasına gelince, karmaşık bir manzarayla karşılaşırız. Kimi ayrıcalıklı yakınlara açı̆̆ızdır, ama başkasına karşı çoğu kez kapalı olmayı sürdürürüz. Örneğin sinema, öznelliğimizin tüm yönlerini yansitma ve özdeşleştirme yoluyla teşvik ederek, gündelik yaşamda bize yabancl ya da antipatik olabileceklere yakınlık duymamızı ve onları 
anlamamızı sağlar. Sokakta karşılaştı̆̆ bir serseriden iğrenen biri, sinemada serseri Şarlo'ya yürekten sempati duyar. Gündelik yaşamda maddi ve manevi yoksullar karşısında bütünüyle kayıtsız kalsak da, roman okurken ya da bir film seyrederken merhamet duyarı ve sefaleti paylaşı$r ı$ (Morin 2013, 72).

Neden böyle bir algı farklılığı ortaya çıkmaktadır? İnsanın iç dünyası ile dışa yansıttığı dünyası arasında neredeyse gözle görülür farkların mahiyeti nedir? Bu salt bir algı ve kavrayış sorunu mudur? Yoksa asıl sorun, estetik objeden etkilenen insanın, estetik süjenin kendisi midir?

O halde insan nedir ve estetik yargılara nasıl ulaşır? Sanat, insan yaratısı iken tekrar nasıl olur da buradan yola çıkılarak yine insana dönen bir terapiden söz edilebilir? Hem sanat üreten hem de sanat terapisi uygulanan varlık olarak neden yine insan olmaktadır? O halde insan nedir

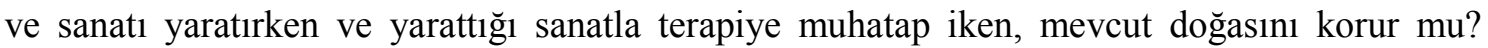
Yoksa estetik süje olmak ile sanat terapisinin "müssterisi” ya da "hastası" olmak, iki farklı insan doğasının olduğunu mu gösterir?

\section{B. İnsanın Doğası ve Sanat-Hayat}

"Hayatın sanatı, sanatın hayatı taklit ettiğinden daha çok taklit ettiğini ileri sürüyorum. Bunun nedeni, yalnızca hayatın kendisinin taklitçi oluşu değil. Asıl neden şu: Hayatın amacl, kendini ifade tarzı bulmaktır ve sanat, bunu gerçekleştirmesi için hayata harika formlar sunar".

Oscar Wilde (Artun 2015).

İnsan nedir? sorusu, felsefe tarihi boyunca neredeyse tüm filozofların ve felsefe sistemlerinin esaslı sorusu olmuş; birbirinden insan ve doğasını betimlemeye çalışan yanıtlar verilmiştir. Ancak insanı ve onun doğasını tanımaya hatta tanımlamaya dönük bu yanıtlar, hiç olmazsa Otto Rank'ın $(2013,45)$ deyimiyle onun "karmaşıl" ve “çok yönlü” bir insan-hayvan olduğu tespitinde birleşmektedir. Sanat ve ahlak, bu karmaşık doğayı en kapsamlı şekilde sergilemede ortaktırlar. Çünkü her ikisi de, doğaları bakımından bu karmaşık doğalı süjelerinin eseridir.

İslam filozofları ve mutasavvıflarının pek çoğu, insan doğasının karmaşık bir yapıda olduğu tespitini belki yüzyıllar öncesinden görmeyi başarmışlardır. Ihvan-1 Safa (X. yüzyıl) (Filiz 2010, 81-142), Haris b. Esed Muhasibi (Ö. 857) (el-Muhasibi 2011, 25-96) İbn Miskeveyh (Ö.1030) (Fahri 2014, 25,28), Ebu Hayyan Tevhidi (Ö. 1023) (Fahri 2014, 93, 99, 100) bunlardan sadece bir kaçıdır.

Ebu Hayyan Tevhidi, insan nedir? sorusuna insan doğasının karmaşık yapısını sergilercesine şöyle yanıt verir:

İnsan, karakteri ve doğası (tiynet) bakımından bir şahıs, ruhu ile bir zat (özne, kendilik, öz), nefsiyle bir töz, akliyla bir tanrı, birlik'te bütün, çoklukta bir, duyularlyla ölümlü, nefisyle sonsuz, hareketli oluşuyla ölümlü, mükemmeli aradı̆̆ için diri, muhtaç oluşuyla eksik, istemesiyle tam, görünüşü önemsiz, ylkıcılıkta tehlikeli, evrenin özü, gözbebeği, onda her şeyden bir parça vardir. Her şey onun için birbirine tutunur, onu yokluktan çekip çıkaran atasina dek uzanan düzgün bir nesebi vardır. Insanla ilgili çok şey söylenebilir. Strları tuhaftır. Onu bilen, alemi ve içindekileri tümüyle tanımış olur. Bildiği ve gördüğü her şeyden kuşku duyan bir töze sahiptir. $O$, görünmeyen her şeyin örneği, tüm görünenlerin de temsilcisidir (Tevhidi 1929, 374). 
Otto Rank'ın XX. yüzyılda insanın karmaşık bir varlığa sahip olduğu tespitini, Ebu Hayyan Tevhidi XI. yüzyılda böyle dile getiriyordu. İnsan, beden ve duyguları ile hayvan-insan, sahip olduğu akıl ve bununla ürettiği kültür ve semboller bakımından da, insan-hayvandır. Yaşamı, bu iki katlı benliği ya da varlık yapısı arasında sürekli gidip gelir. Benliğinin bir yanına ya da bu benliklerden herhangi birinin şu ya da bu eylemine bakılarak, insanı tek yanlı tanımlamak onu tanımamak anlamına gelir ki, modern çağın en büyük sorunlarından birisi budur. İnsanın anlaşılmasında en yanlı ve hatalı tanımlamalar, onun içsel benliği, başka bir deyişle, insanhayvan varlığına ilişkin olanlardır.

\section{1. İçsel Benlik}

İçsel benlik düşünce özgürlüğünü, hayal gücünü ve sembolizmin sonsuz uzaklığını; beden, belirlenimi ve sınırlılığı temsil eder. İç benlik, bedensel benlik ve cinsel dürtüler bu çok yanlılığı örnekleri arasında önemli bir yer tutar.

"Suçluluk duymadan seks yapmanın bu kadar zor olmasının nedeni budur: suçluluk mevcuttur, çünkü beden kişinin içsel özgürlüğünü karartır, onun 'gerçek' benliği-seks eylemi vasitasiyla-standartlaşmış, mekanik, biyolojik bir role zorlanır. Hatta daha kötüsü, içsel benlik kesinlikle hesaba katılmaz; beden tamamen toplam bireyin sorumluluğunu üstlenir, bu suçluluk türü içsel benliği sindirir ve yok olmanın habercisidir... Bu yüzden bir kadın, erkekten 'yalnızca bedenimi' değil, 'beni' istiyor güvencesini talep eder; kadın şeklen kendi ayırıcı içsel kişiliğinin cinsel eylemle ortadan kaldırllabileceğinin bilincindedir” (Becker 2013, 77-78).

Bedensel faaliyetin en önemlisi, cinsel birleşmedir. Tüm canlılarla paylaşılan bu ortak özellik, insanda biyolojik benlikte insani benliğini kaybetme endişesi yaratır.
“Aşk, bu tür cinselliğin tek önemli anahtarldır, çünkü bireyin korku ve suçluluk duymaksızın hayvani boyuta inişine, ancak ayırıcı içsel özgürlü- ğ̈̈nün hayvani bir feragat tarafindan geçersiz kılınmayacağına inanç ve güvenle izin verir" (Becker 2013, 78).

Soren Kierkegaard'ın deyimiyle insan mekanik bir evrenin kölesi değil, verdiği kararlarla kendi geleceğini ve sonuçta kendi özünü teyit etme kapasitesine sahip, özgür iradeli bir kişiliktir. Soyut düşünce hayal dünyasına kaçmak yerine insanların bütün çeşitliliği ile hayata bağlanmalarına gösterilen ilgidir (Billington 1997, 56).

Peki, Kierkegaard'ın tanımı ve önerisini kabul ettiğimizde insanın "karmaşık” yapısı bütünüyle açılanmış olur mu? "Normal” insanlar olmak için bu öneriyi izlemek yeterli midir?

O halde "normal insan" kimdir?

"Normal olarak yaşamak için, insanoğlu başlangıçtan itibaren dünyayla ve kendisiyle ilgili ciddi bir bastırma yeteneği kazanmak zorundadır. Normalliğin özünün, gerçekliği inkar etme olduğunu söyleyebiliriz. Nevroz dediğimiz şey, kesinlikle bu noktada devreye girer: Bazı insanlarin yalanlartyla ilgili diğer insanlardan daha fazla sorunu vardır. Hayat onlara çok fazla gelir ve hayatı uzak tutmak ve önemsizmiş gibi göstermek için geliştirdikleri teknikler, nihayet kişinin kendisini boğmaya başlar. Bu kısaca nevrozdur: Gerçeklik hakkinda yalanları harekete geçirememe yeteneksizliği”" (Becker 2013, 246). 
Gerçeklik hakkında yalanları harekete geçirme yeteneği, normal insanların genel özelliğidir. Bu konudaki başarısızlık, nevrotik sınırın üstüdür ve insan normallikten çıkar.

Harold F. Searls, nevrotik normaller hakkında daha ayrıntılı açıklamalar yapar.

Carl Gustav Jung bütün insanların kolektif bilinçaltı ile doğduklarına ve bütün kültürlerde ortak evrensel arketipler bulunduğuna inanmaktadır (Storr 2006, 307). Geniş ölçüde sanatsal geleneklere yayılmış görsel sembolizmin benzerliği bu hipoteze ilişkin kanıtın bir kısmıdır. Jung'un sembolizm anlayışı Freud'unkinden oldukça farklıdır. Freud sembollerin, bilinçdışı duyguları ve fantezileri gizleme gücüne inanırken, Jung, sembollerin gizli fikirleri (ideaları) ortaya çıkarma kapasitesinden söz eder. “Görsel sembollerde 'işitilen' mesajlar vardır. Zihinsel ve sanatsal imgelere Jung'un yaklaşımı saygıdeğerdir ve sezgiseldir. Ancak Freud'unkinden daha az analitik ve daha az tümdengelimlidir” (Rubin 2010, 98).

Freud'un hem öğrencisi hem de eleştiricisi olan Otto Rank, sembollerle nevrozlar arasında farklı bir ilişki olduğunu öne sürer. $\mathrm{O}$, sembollerin analitik ve tümden gelimsel gücü bir yana, asıl olarak onların sanat yoluyla nevrozlarla ilişkisini varoluşsal yöntemle açıklar. Sanat, sıra dışı hale getirdiği sembollerle varoluşun sürekliliğini nasıl sağlamaktadır? Sanat ile terapide semboller ve simgeler nasıl bir yere sahiptir?

İnsan bunun nasıl sonuçlanacağını ya da kendinin ne kadar aptalca görüneceğini asla bilmez, ancak nevrotik bu tip garantilere ihtiyaç duyar. Kendi benlik imajını riske sokmak istemez. Rank buna "benliğe aşırı değer biçmekte kararlı olma" der, nevrotik bu yolla doğayı aldatmaya çalışır. Nevrotik doğanın ondan yoksun olmasının bedelini ödemez. Yaşlanmak, hasta olmak ya da sakatlanmak ve ölmek. Hayatı yaşamak yerine, nevrotik onu tasavvur eder; onu eylem halinde düzenlemek yerine, tamamen zihninde tasarlar.

"Nevrotik, biyolojik olarak yaşamak yerine, sembolik olarak yaşar. Doğanın sunduğu kısmi şekilde yaşamak yerine, sembollerin mümkün kıldı $\breve{g}$ total şekilde yaşar. 'İnsan benliği'nin sihirli, her şeyi kapsayan dünyasını gerçek, bölük pörçük dünyanın yerine koyar. Bu anlamda bir kez daha herkes nevrotiktir, çünkü herkes bazı yönlerden hayattan kaçınır ve sembolik dünya görüşünün olayları düzenlemesine izin verir, kültürel ahlakın nedeni budur. Bu anlamda en nevrotik olan kişi sanatçıdır, çünkü hayatı bir bütün olarak benimser ve genellikle ondan sembolik bir problem üretir" (Becker 2013, 252-253).

Nevroz ve nevrotiklik sanatçılara ait bir problem değildir. Hepimiz aynı problemle yüz yüzeyiz. Nevroz sorunu bu bakımdan klinik bir problem değil, felsefi bir problemdir; insan varoluşunun en başat belirleyicisidir. Eğer sanatçı, normal nevrotiklik sınırını aşıyorsa, yarattığı estetik obje ve estetik tutumu, başkası için terapatik değer taşır mı?

\section{Sanatla Felsefenin Buluşma Noktası}

Sanatla felsefe kavramsal çözümleme ile nerede buluşmaktadır?

Sanat etkinliği ya da estetik bir tavır, öncelikle ontolojiye dayanır. Sonra epistemolojik bir sorun haline gelir. Estetik süje ile estetik obje arasındaki bağ, epistemolojideki süje-obje bağından farklı değildir. İlkinde estetik yargı, ikincisinde epistemik yargı ortaya çıkar. İlki, güzelçirkin kategorisini, ikincisi doğru-yanlış kategorisini verir.

"Plotinus'a göre, nesneler ve ruhun akrabalı̆̆ formdan (ideadan) pay almakla olur. Çünkü şekilsiz olan her şey, şekil ve form almak için belirlenmiştir. Fakat kavram ve formdan pay almadı̆̆ müddetçe çirkindir. 
Çirkin, formun ve ideanın hâkim olamadiğg şeydir. Tanrısal akıldan pay almamıştır. Güzel bunun tersidir. Algı dünyası ruhun bir taşmasıdır ve bu bakımdan da bir forma sahiptir" (Tunalı 1983, 44).

"Plotinus'ta duyulur dünyanın güzelliği renk, form ve ses kategorisi içinde kendini gösterir. Hegel de güzeli, ideanın maddede forma ulaşması diye tanımlar" (Tunalı 1983, 49). Dolayısıyla Plotinus bu noktada Hegel'in habercisidir.

İdea, metafiziksel bir öz; tinsel bir anlamdır. Bu anlam maddede forma girer. Sanatçı, Tanrısal ideayı maddede bir biçime, forma sokar. Düzenler, simetri ve uyum oluşturur. Tıpkı günlük hayatımızda, düzen, şekil ve simetri ile form vererek varoluşumuzun devamlılığını, hiç olmazsa, geçici yaşam pratiklerimizi gerçekleştirmeyi sağlamaya çalıştı̆̆ımız durumdur. Bu çaba estetik açıdan değer ifade etmese de, formu idea düzeyinde içeriklendirdiğimiz, geçici formlar yerine estetik değere haiz formlar yarattığımızda, sanat icra etmiş oluruz. İkincisi, hem felsefi hem de terapatik değeri olan sanat etkinliğidir. Estetik etkinlik, bir ruh etkinliğidir. Doğrudan doğruya insandan doğar ve en yüksek tinsel yaratı olarak yine ona döner. Amaç, biyolojik: hayvan-insanı, kültürel/simgesel insan-hayvan olarak inşa etmektir. Dışkılayan ve üreyen bir hayvan-insanlıktan, kültür ve simgeler yaratan bir insan-hayvana evrilmenin ontolojik zemin üzerinde estetik objede ahlaki-tinsel ideanın en yüksek forma girmesidir. $\mathrm{Bu}$ forma girmenin ontolojik, epistemolojik temeli üzerinde ahlak ve estetik birleşir; tanrısal bir yüceye ulaşır; bu noktada varlığın, bilgi ya da etik herhangi bir ilkenin neliği (mahiyeti) sorgulanmaktan çok, estetik değerin insan-hayvanı varoluş olarak devam ettirecek terapatik gücü öne çıkar.

Zamanın öldüremeyeceği bir ruh kazanmak için bedenlerimizi bastırırız; ölümsüzlüğü satın almak için hazzı feda ederiz; ölümden kaçınmak için kendimizi küçültürüz. Dolayısıyla biz karakterin savunması için de sıkışırken, hayatı uzatırız. Jung'a (2013, 49) göre, insanların karanlık yanı olan aşağılık, kendinden nefret etme suçluluk, düşmanlık duygularını bir düşmana yansıtarak mücadele etmektedirler. Zamanımızın bilgili insanı, hiç hayal edemeyeceği ağır bir sorumluluk altında eziliyor: Tüketilemeyen hakikatin aşırı üretimi (Becker 2015, 69). Psikanalist Gregory Zilboorg $(1967,279)$ da, insanların yaşadıkları tehlikeli dünya ile sınırlı güçlerinin gerçek ilişkisini görmek zorunda olduklarını söyleyerek nevrotik terapinin bir varoluş sorunu olduğuna dikkat çekmektedir.

İnsan, kendi varlığını ve varoluş sürecini devam ettirmek için Tanrısal olana başvurur. Otto Rank’e $(2001,57)$ göre insan, varlığını ancak kendi egosu dışında inşa edilen bir tanrı idealiyle uyum içinde yaşayarak sürdürebilir. Rank, psikanalitik klinik anlayışıyla insan yaratığının temel ontolojik güdülerini ilişkilendirir. Ölümsüzlük dürtüsü, ölüm kaygısının basit bir refleksi değil, insanın bütün varlığının hayata bir uzanışıdır. Yaratık bilinci kültür tarafından daima emilir. Kültür doğaya karşı koyar ve onu aşar. Kültür, en basit tanımıyla insanlaşamamanın kahramanca bir reddidir.

Ölüm kaygısı yüzünden varoluş çok büyük bir yüktür; nesneye tutunma ve bedensel çürüme evrensel olarak insanların kaderidir. Bir tür meşrulaştırma ideolojisi olmadığında insanlar doğal olarak çıkmaza girer ve hüsrana uğrarlar (Becker 2013, 89). Bu ideoloji, Husserl'e göre (Mengüşoğlu 1945, 47-74), bir tür kavramsal ve diskürsif kavrayıştan ziyade, bilincin dolayıms1z idrakinden, doğrudan deneyiminden gelmek durumundadır. Husserl, sadece fenomenlerin gerisindeki gerçekliklerin dolayımsız bir takım görüleme formlarıyla bilinebileceğini kabul eden filozoflara değil, bir yandan bilen zihin ile diğer yandan bilinen nesne arasında bir ayırım yapan filozof veya bilgi kuramlarına da karşı çıkar. Çünkü Husserl, en azından ilk ve temel deneyimde, bilinç ile fenomen arasında bir ayırım yapmaz. Husserl'in tutumunu veya yaklaşımını eşsiz kılan şey de onun var olanın veya fenomenlerin kendilerini bilince sunan öznel edimde 
içerildiğini öne sürmesidir (Cevizci 2009, 950).

Edmund Husserl'in adıyla anılan fenomenoloji XX. yüzyıl psikolojisine derinlemesine etkide bulunmuştur. Bu kuramın önemi, zaman sürecinin her anında gerçekliğin her birey tarafindan tecrübe edilmesinin eşsizliğinden kaynaklanmaktadır. Örneğin Mela Betensky, Gestalt psikolojisinin unsurlarını içinde bir araya getirdiği fenomenolojiye dayanarak yaklaşımını geliştirmiştir (Rubin 2010, 75). Varoluşçuluk ile fenomenoloji birbiri içindedir. Psikolojinin varoluşçu temel kadar fenomenolojik temellere dayandığını vurgulamak gerekir. Varoluşçuluk ve fenomenoloji, kıta felsefesi veya analitik felsefeye bir eleştiri olarak ortaya çıkarken, psikoloji başta olmak üzere olgucu-bilimsel yöntemin tüm insan bilimlerini belirlemesine de karşı çıkmıştır. Böyle olunca eleştirel felsefenin bu iki akımı, psikoloji ve sanatı yeniden felsefeyle, insanbilimlerinin yöntemiyle buluşturmanın ifadesi olmuştur. Eleştiri felsefesiyle insan meselesi üzerinde dikkatini yeniden insan üzerinde odaklayan felsefe, çağımızda sanat ve psikolojinin modern çă̆ın sıkıntılarından bunalan insanlığa yepyeni bir terapi imkanı olma ihtimali üzerinde durmaya başlamıştır.

Çok eski bir terapi şekli diye kabul ettiğimizde sanat terapisi, varoluş̧̧u ve fenomenolojik kökenleri ile yeniden buluşmakta; bu eleştiri çağında psikoterapi felsefeden kopan diğer alanlarla geleneksel ilişkisini kurma yoluna gitmektedir. Psikoterapi, Otto Rank'ın çalışmalarıyla, analitik yöntemin olgucu yaklaşımındaki dar alandan kurtulup, fenomenolojik yöntemin manevi ve kültürel zenginliğine sahip post-modern yaklaşımın tüm çeşitliliği ile açılan kültürel, simgesel alanına yayılma olanağına kavuşma yoluna girmiştir. Psikoterapi, insanı holistik kavrayabilecek tüm yapıp-etmeleriyle, kültürel ve simgesel varlık alanıyla ilişki kurarak tek yanlı, analitik ve pozitivist bakış açısının yetmediğini görmüştür. İnsan kültürünün en etkili ve kapsayıc1 etkinliği olan sanat, işte bu yolla psikoterapiye katkı sağlar.

Terapinin doğrudan ve zengin bir beslenme kaynağ 1 olur. Bu buluşmayı sağlayan ise felsefedir. Sanat böylece, felsefenin yaptığını yapar; felsefi terapinin estetik yanını temsil eder. Estetik felsefe, tıpkı, kedisinden kaynaklandığı salt felsefe gibi, kişiyi bütün olarak kapsar ve kavrar. İnsanın bedeni, zihni ve ruhunu sentezler. Hıristiyan ermiş Assisili Francesco'nun deyimiyle, "Elleriyle çalışan, iş̧̧idir; elleri ve kafasıyla çalışan zanaatkârdır; elleri, kafası ve kalbiyle çalışan ise, sanatçılır" (Rubin 2010, 85). Klinik nörobilim alanında yapılan son zamanlardaki araştırmalar, beyin fizyolojisi ile sanat yaratımı arasında daha fazla ilişski olduğu yönündedir (Rubin 2010, 85).

Ancak sanat, Francesco'nun vurguladığı gibi salt beyinle üretilen bir yaratı değildir. Sanat insana ve dünyaya bütün olarak bakar. Rank’a göre sanatçı, bütün dünyaya sahip çıkar, dünya tarafından yönetilmek yerine, onu kendi kişiliğinde yeniden şekillendirir ve sanat eserinde yeniden yaratır. "Nevrotik ise kesinlikle bunu yaratamayan kişidir... O sanatkâr" olamamıştır. Hem sanatkârın hem de nevrotiğin üstesinden gelemeyecekleri işlere kalkıştıklarını söyleyebiliriz, ancak sanatkâr bu işi kendinden çıkarır ve dışsal, aktif bir sanat projesi olarak objektif bir şekilde üstesinden gelir. Nevrotik, çok özel bir eserde somutlaşmış bu yaratıcı tepkiyi düzenleyemez ve dolayısıyla içe dönüşlerinde boğulur. Sanatkâr da, ayn geniş kapsamlı içe dönüşlere sahiptir, ancak onları araç olarak kullanır" (Becker 2013, 253).

Sanat etkinliği sadece sanatkara dönük bir etkinlik ve terapi değildir. Estetik suje belki bu sanat etkinliği ile kendinden başkalarını hedefler; estetik haz ve terapi, en çok başkalarına dönüktür.

Genel olarak sanat, olumsuz fikir ve duyguların boşaltılması için en iyi terapi yollarından biridir. Bu tip fikir ve duygular, sanat aracılığıyla "güzel" ya da "yüce" ideasının estetik forma sokulup düzenlenmesiyle; simetri, oran ve biçime kavuşmasıyla, iyileştirilebilir. Olumsuz 
fikirler ve duygular sanat yoluyla daha kolay dile getirilebildiği için (Becker 2013, 81) sanatç1nın yarattığı kendine ait öznel dünyanın dışavurumunda forma sokulabilir. Çirkinin estetik idea ile "güzel” formuna, "kötü" nün aksiyolojik idea ile "iyi" formuna sokulması, "güzel” ile "iyi”"nin Kant'ın "Yüce” kavramıyla adlandırdığı erdemde birleşir. Sanat ile ahlak, bu kez, form vermede birleşir. Her ikisi de form vererek sağaltır. Sağaltım, "hasta-doktor" ilişkisiyle sınırlandırılabilecek klinik bir vak'aya işaret etmez. Aksine, sanat ve ahlak terapisinde "hasta" da, “doktor” da, öznedir, yani tüm insanlardır.

\section{3. Ölüm Kaygısı}

Peki, bu aksiyoloji ile birlikte bu varoluşsal terapiyi sanat, hangi amacı kollayarak gerçekleştirmeye çalışır? Başka bir deyişle, sanatla terapi, insanlarda hangi sorunun anlamlandırılmasına odaklanır?

Felsefenin bütün terapatik imkânlarıyla oluşan sanat terapisi, varoluşsal bir sorun olan ölüm kaygısını bastırmada insana en hayati desteği sağlar. Ölüm korkusunu ya da duygusunu bastırma, sıradan bir unutma ya da askıya alma girişimiyle açıklanamaz. Varoluşun sürekliliği başat amaçtır ve varoluş, ölüm korkusuyla sekteye uğramaksızın sürebilmelidir. Gregory Zilboorg, ölüm korkusunun bütün normal işleyişimizin arkasında mevcut olması gerektiğine inanır. Ancak ölüm korkusu bir insanın zihinsel işleyişinde sürekli mevcut olamaz, aksi takdirde organizma işlevini yerine getiremez "Eğer sürekli bu korkunun bilincinde olunsaydl, normal olarak çalışmamamız gerekirdi. Hayatımızı birazcık huzurla sürdürebilmek için korku tamamen bastırılmalıdır. Bastırmanın, kötüleri biriktirmek, biriktirileni ve koyduğumuz yeri unutmaktan daha ötede bir şey anlamına geldiğini çok iyi biliyoruz. Bu, sürekli bir psikolojik kapalı tutma çabasını sürdürme anlamina da gelir ve asla içteki tedbirliliğimizi yumuşatmaz” (Becker 2013, 47).

Ölüm korkusunu bastırma, insanın tüm simgesel varoluşuyla üstesinde gelmesi gereken kesintisiz bir travmaya sanat yoluyla karşı koymanın adıdır. Psikoloji, modern çağın, kıta felsefesiyle yoğun eleştirisine maruz kalan analitik yöntemi aşarak fenomenolojik yönteme başvurmak zorundadır. Çünkü insan varlığı bütüncül bir varoluşun kesintisiz olmasını şart koşar. $\mathrm{Bu}$ varoluşu, yaşamın her anında kesintiye uğratma tehdidinde bulunan ölüm duygusunu, çağımızda felsefenin bütün alanlarıyla yeniden buluşarak sürdürmek zorunluluğu ile karşı karşıyadır. Bertrand Russell, mantıksal çözümlemenin konusu olmayan hiçbir sorunu, felsefi bir sorun görmezken, başka bir ifadeyle, her felsefi sorunu mantıksal-matematiksel bir çözümlemenin konusu kabul ederken (Hospers 1997, 175) analitik düşüncenin bilimsel metoduna psikolojinin de hapsolacağını belki tahmin edemedi. Ancak bu gerçekleşti. Oysa psikoloji, bu dar ve indirgemeci modern bilim yöntemine sıkışıp kalınca, insan ve onun inşasını sağlayan her türlü kültürel ve simgesel dünyadan mahrum kaldı. Hem insan doğasını hem de hayatın nihai anlamını ele aldıkları için din ve psikiyatrinin ne kadar ayrılamaz olduğu ortadadır.

“Otto Rank, insanoğlunun, kâinatın büyüleyici aşkınlı̆̆ karşısında doğal aşağllık duygusunu hissettiğini söylerken, modern yöntemle yetinen psikolojinin bu devasa travmayl, insanın kültürü, sanatı ve tüm yapıpetmelerini dışarıda bırakarak anlamaya çalışmasını beyhude bulmakta haklıdır. Ona göre bu duygu, insanın, varoluşun ezen ve etkisiz hale getiren mucizesi karşısındaki gerçek yaratık duygusudur. Artık bir dini tecrübe fenomenolojisinin psikolojiyle ne kadar ilişkili, cesaret problemiyle nasıl doğrudan bağlantıl olduğunu görüyoruz. Rank, insani hayvan, diğer hayvanların muaf olduğu iki büyük korkuyla karakterize edildiğini öne sürer: Hayat ve Ölüm korkusu” (Becker 2013, 87). 
Din, kültür, tarih ve biyolojinin ortaklaşa ve istisnasız konusu olan insan, hayvan-insan ile insan-hayvan arasındaki sürekli gerilimin yarattığı varoluşsal ölüm duygusunu, bütün bunların birikimiyle yarattığı sanat etkinliği ile bastırarak kendi türünü ömür boyu terapiye tabi tutabilir (Yalom 2015, 67-76). Modern bilim yöntemi yüzünden her biri bir yere dağılmış bunca insan yaratımı ve edimini, ancak felsefeyi sanatla yeniden buluşturarak anlamlandırabilir. Anlamlandırma ve farkındalık yaratma, terapinin en temel amacıdır. Sanatla terapi, felsefenin bu boyutları sayesinde gerçekleşme potansiyeli taşımaktadır.

Sonuç olarak, sanat terapisi, yurt dışında kavram, teknik ve içerikleri hemen hemen belirlenmiş bir terapi tekniği olarak kullanılmaktadır. Kaldı ki, Avrupa'da bile bu haliyle sanat terapisi, neredeyse psiko-terapinin akıbetine uğramıştır. Teknik terapiye indirgendiği için, din ve felsefeyle bağı zayıflamıştır. Ülkemizde ise, sanat terapisi kavramı bile henüz çok yenidir. Kierkegaard'ın psiko-terapinin din ve felsefeyle ilişkisini modern çağda yeniden kurması gerektiği fikrinden hareketle ülkemizde yeni telaffuz edilmeye başlayan sanat terapisinin de din ve felsefeyle bağını güçlendirmesi gerektiğini savunmaktayım. Sanatın birçok alanlarını içermesi bakımından sanatın çeşitli tekniklerini kullanmakla birlikte, tinsel derinliği göz ardı etmeyecek fenomenolojik ve varoluşsal derinliği yakalaması gerekmektedir. 


\section{KAYNAKÇA}

Artun A. (2015). Bir Muamma Sanat Hayat Aforizmalar. İstanbul 2015.

Becker E. (2013). Ölümü İnkâr. Çev. A. Tüfekçi. İstanbul 2013.

Billington R. (1997). Felsefeyi Yaşamak. Çev. A. Yılmaz. İstanbul 1997.

Bradley A. C. (1991). Shakespearean Tragedy: Lectures on Hamlet, Othello, King Lear, and Macbeth. London 1991.

Cevizci A. (2009). Felsefe Tarihi. İstanbul 2009.

Demiralp D. (2015). Antik Dönemde Felsefe ve Sanat. İstanbul 2015.

El-Muhasibi Haris b. Esed (2011). (er-riaye) Nefis Muhasebesinin Temelleri. İstanbul 2011.

Fahri M. (2014). İslam Felsefesi Kelamı ve Tasavvufuna Giriş. Çev. Şahin Filiz. İstanbul 2014.

Filiz Ş. (2010). Ihvan-ı Safa Topluluğu ve İnsan Felsefesi İlk İslam Hümanistleri, Bilim ve Ütopya Kitaplığı. İstanbul 2010.

Hospers J. (1997). An Introduction to Philosophical Analysis. London 1997.

Jung C. G. (2013). Keşfedilmemiş Benlik. İstanbul 2013.

Malraux A. (1994). İnsanlık Durumu. Çev. A. Er. İstanbul 1994.

Mengüşoğlu T. (1945). Fenomenoloji Felsefesi. İstanbul 1945.

Morin E. (2013). Geleceğin Eğitimi İçin Gerekli Yedi Bilgi. Çev. H. Dilli. İstanbul 2013.

Mussenbrock A. (2013). Felsefeyle Terapi. Çev. N. Ermiş. İstanbul 2013.

Rank O. (1989). Art and Artists. New York 1989.

Rank O. (2001). Doğum Travması. İstanbul 2001.

Rubin J. A. (2010). Introduction to Art Therapy. NY 2010.

Storr A. (2006). Jung'dan Seçme Yazılar. Ankara 2006.

Tevhidi E. H. (1929). El-Mukabesat. Ed. Hasan es-Sendubi. Al-Kahira 1929.

Tunalı İ. (1983). Grek Estetik'i. İstanbul 1983.

Yalom I. (2015). Schopenhaur Tedavisi Bugünü Yaşama Arzusu. Çev. Z. Babayiğit. İstanbul 2015.

Zilboorg G. (1967). A History of Medical Psychology. Baltimore 1967.

Zweig S. (1969). Freud ve Öğretisi. Çev. E. Elçin. İstanbul 1969. 